\title{
Linkage analysis in Usher syndrome type I (USH1) families from Spain
}

Carmen Espinós, Carmen Nájera, José Maria Millán, Carmen Ayuso, Montserrat Baiget, Herminio Pérez-Garrigues, Onofre Rodrigo, Concepción Vilela, Magdalena Beneyto

Departamento de Genética, Fac C C Biológicas,

Universidad de

Valencia, C/ Dr

Moliner 50, 46100

Burjassot, Valencia,

Spain

C Espinós

C Nájera

Unidad de Genética y Diagnóstico Prenatal,

Valencia, Spain

J M Millán

M Beneyto

Departamento de Genética, Fundación Jiménez Díaz, Madrid, Spain

C Ayuso

Unitat de Genética, Hospital de la Santa Creu i Sant Pau, Barcelona, Spain M Baiget

\section{Servicio de}

Otorrinolaringología,

Hospital La Fe,

Valencia, Spain

H Pérez-Garrigues

O Rodrigo

\section{Unidad de}

Neurofisiología,

Hospital La Fe,

Valencia, Spain

C Vilela

Correspondence to:

Professor Nájera.

Received 21 January 1997 Revised version accepted for publication 22 October 1997
Hospital La Fe,

\begin{abstract}
Usher syndrome (USH) is an autosomal recessive hereditary disorder characterised by congenital sensorineural hearing loss and gradual visual impairment secondary to retinitis pigmentosa (RP). The disorder is clinically and genetically heterogeneous. With regard to Usher type I (USH1), several subtypes have been described, the most frequent being USH1B located on chromosome 11q13.5. Of 18 USH1 families studied by linkage analysis, $12(67 \%)$ showed significant lod score values for locus D11S527 (Zmax=14.032, $\theta=0.000)$ situated on chromosome $11 q$. Our findings suggest considerable genetic heterogeneity in the Spanish USH1 population. It is important to note that one of our families linked to the USH1B locus shows interesting intrafamilial clinical variability. As regards the remaining six USH1 families, the linkage analysis did not provide conclusive data, although two of them show slight linkage to markers located on chromosome 3q (Zmax $=1.880$, $\theta=0.000$ for D3S1279), the same location that had previously been assigned to some USH3 families.
\end{abstract}

$(\mathcal{O}$ Med Genet 1998;35:391-398)

Keywords: Usher syndrome; linkage analysis; genetic heterogeneity

Usher syndrome (USH), which is recognised as the most common cause of combined deafness and blindness in adults, is an autosomal

Table 1 Characteristics of polymorphic markers on chromosome $11 q$ used in the present study

\begin{tabular}{llllll}
\hline Locus & Primers & Alleles & Size $(b p)$ & Annealing temp & References \\
\hline ROMI $^{\star}$ & ROM1/2 & & & $55^{\circ} \mathrm{C}$ & 26 \\
INT2 & FGF3 & 9 & $161-177$ & $55^{\circ} \mathrm{C}$ & 27 \\
D11S916 & AFM185yal & 9 & $135-153$ & $60^{\circ} \mathrm{C}$ & 29 \\
D11S527 & JG4-A/JG4-C & 12 & $146-166$ & $55^{\circ} \mathrm{C}$ & 30 \\
OMP & OMP & 4 & $244-254$ & $55^{\circ} \mathrm{C}$ & 28 \\
D11S911 & AFM155xh10 & 13 & $159-203$ & $50^{\circ} \mathrm{C}$ & 29 \\
D11S35 & $780 / 781$ & 6 & $152-162$ & $40^{\circ} \mathrm{C}$ & 31 \\
D11S528 & $42026 / 42027$ & 6 & $188-208$ & $50^{\circ} \mathrm{C}$ & 32
\end{tabular}

${ }^{\star}$ ROM1/2 marker was studied by means of SSCP.

Table 2 Characteristics of microsatellite polymorphisms on chromosome $3 q$ used in the present study

\begin{tabular}{llllll}
\hline Locus & Primers & Alleles & Size $(b p)$ & Annealing temp & References \\
\hline RHO & RHO & 4 & 120 & $57^{\circ} \mathrm{C}$ & 33 \\
D3S1555 & AFM056xf12 & 8 & $221-237$ & $55^{\circ} \mathrm{C}$ & 29 \\
D3S1308 & AFM240ve1 & 5 & $104-112$ & $50^{\circ} \mathrm{C}$ & 29 \\
D3S3705 & AFMa043tf5 & 5 & $228-236$ & $55^{\circ} \mathrm{C}$ & 29 \\
D3S1299 & AFM220yh12 & 6 & $218-228$ & $53^{\circ} \mathrm{C}$ & 29 \\
D3S1279 & AFM164xg9 & 10 & $264-282$ & $55^{\circ} \mathrm{C}$ & 29 \\
\hline
\end{tabular}

recessive hereditary disorder characterised by congenital sensorineural hearing loss and gradual visual impairment secondary to retinitis pigmentosa (RP). ${ }^{12}$

The disorder is clinically heterogeneous and, at present, three types can be distinguished on the basis of clinical findings principally related to audiological and vestibular parameters. ${ }^{3-7}$ Usher type I (USH1) patients suffer severe to profound congenital hearing loss and abnormal or absent vestibular response, whereas Usher type II (USH2) is characterised by moderate to severe congenital hearing loss and normal vestibular function. Usher type III (USH3), which is clinically similar to USH2, is characterised by the progressive nature of its hearing loss and by the mild vestibular dysfunction. Although retinitis pigmentosa has been accepted as occurring earliest in type $I$, the ocular data are insufficient for distinguishing between types. It is interesting to note that a number of heterozygous carriers have shown significant audiological and ophthalmological abnormalities. ${ }^{89}$

Genetic heterogeneity for USH1 and USH2 has been verified by linkage analysis. At least six different loci have been located: USH1A on $14 \mathrm{q}^{1011}$ USH1B on $11 \mathrm{q}^{12}{ }^{13}$ USH1C on $11 \mathrm{p},{ }^{14}{ }^{15} \mathrm{USH} 1 \mathrm{D}$ on $10 \mathrm{q},{ }^{16}$ USH1E on $21 \mathrm{q} 21,{ }^{17}$ and USH2A on $1 \mathrm{q} .{ }^{18}{ }^{19}$ There are, however, families of both types which fail to show linkage to any of these regions. ${ }^{11}{ }^{17}$ As far as USH3 is concerned, a notable clustering has been observed in eastern Finland. Sankila et $a l^{20}$ assigned an USH3 locus to chromosome $3 \mathrm{q}$. Furthermore, some USH2 families have been linked to the USH 3 locus. ${ }^{21}$ To date, only one gene related to USH is known, myosin VIIA, an unconventional myosin, involved in the USH1B phenotype. ${ }^{22-24}$

In the present study, the results of linkage analysis in 18 Spanish USH1 families are reported.

\section{Material and methods}

FAMILIES AND CLINICAL STUDIES

Eighteen Spanish families clinically diagnosed as having USH1 with a total of 34 affected patients ( 23 males and 11 females) have been studied. Most of these families have multiple affected children and four show consanguinity. Patient II.4 of family 11 (fig 1) shows peculiar clinical features, since he suffers prelingual profound deafness and vestibular dysfunction; however, to date (39 years old), he has not shown any symptons of RP. Moreover, he is also severely mentally retarded. In the remaining patients, mental retardation or physical dysmorphology were not noted. 

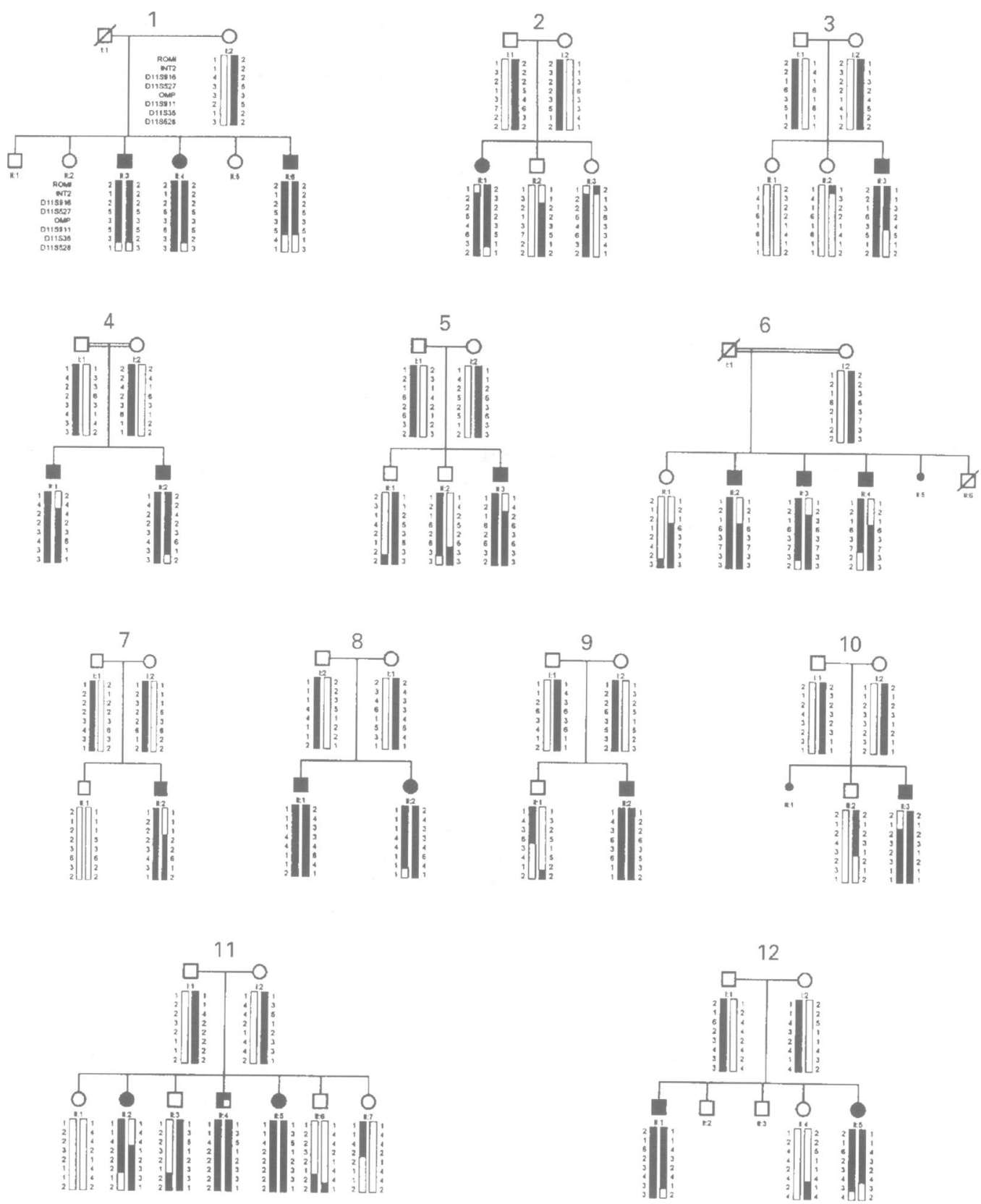

Figure 1 Pedigrees and haplotypes of the 12 Usher syndrome type I families linked to 11q. Haplotypes were constructed based on the minimum number of recombinations between these markers.

Clinical tests were performed on all affected subjects. The ophthalmological studies included determination of visual acuity, fundus ophthalmoscopy, visual field examination, electroretinography, and visually evoked potentials. The diagnostic criteria used to recognise $\mathrm{RP}$ were night blindness, loss of visual field and acuity, and altered or unrecordable electroretinogram. The otolaryngological evalua- tion included audiological examination, neurootological exploration, electronystagmography, and posturography.

DNA STUDIES

DNA was extracted from peripheral blood leucocytes from each person. ${ }^{25}$ PCR amplifications were performed in a total volume of $50 \mu \mathrm{l}$ containing $200 \mathrm{ng}$ of human genomic DNA, 50

Table 3 Lod scores of chromosome 11 markers versus Usher type I in the 12 linked families

\begin{tabular}{|c|c|c|c|c|c|c|c|}
\hline & \multicolumn{7}{|c|}{ Recombination $(\theta)$} \\
\hline & 0.000 & 0.010 & 0.05 & 0.10 & 0.20 & 0.30 & 0.40 \\
\hline ROMI & $-\infty$ & 2.440 & 3.356 & 3.355 & 2.732 & 1.823 & 0.789 \\
\hline INT2 & $-\infty$ & 4.344 & 5.902 & 5.953 & 4.788 & 3.105 & 1.314 \\
\hline D11S916 & $-\infty$ & 1.522 & 4.784 & 3.970 & 4.725 & 3.192 & 1.369 \\
\hline D11S527 & 14.032 & 13.998 & 12.770 & 11.224 & 8.120 & 5.008 & 2.001 \\
\hline OMP & 7.259 & 7.114 & 6.520 & 5.755 & 4.168 & 2.556 & 1.000 \\
\hline D11S911 & 13.524 & 13.253 & 12.151 & 10.740 & 7.845 & 4.883 & 1.970 \\
\hline D11S35 & $-\infty$ & -8.456 & -4.792 & 0.459 & 1.508 & 1.122 & 0.511 \\
\hline D11S528 & $-\infty$ & -0.909 & 1.931 & 2.606 & 2.418 & 1.611 & 0.653 \\
\hline
\end{tabular}


Distance (KcM)

4.0

3.5

0.5

1.0

18.0

Figure 2 Genetic distances (KcM: Kosambi centimorgans) and locus order of the $11 q$ markers used in the study. Data were obtained from Genome Data Bank (GDB) and van Heyningen and Little."

$\mathrm{mmol} / 1 \mathrm{KCl}, 10 \mathrm{mmol} / \mathrm{l}$ Tris- $\mathrm{HCl}, \mathrm{pH} 8.3,1.5$ $\mathrm{mmol} / 1 \mathrm{MgCl}_{2}, 100 \mu \mathrm{g} / \mathrm{ml}$ gelatin, $200 \mu \mathrm{mol} / 1$ $\mathrm{dNTP}, 1 \mu \mathrm{mol} / 1$ of each primer $(50 \mathrm{pm})$, and 1 unit of Taq DNA polymerase. The polymorphic microsatellite markers and their PCR conditions are given in tables 1 and $2 .{ }^{26-33}$ The amplified DNA was electrophoresed on a $8-12 \%$ polyacrylamide gel and stained with silver. The marker $R O M 1 / 2$ was analysed by SSCP with electrophoresis on a polyacrylamide gel containing $5 \%$ glycerol.
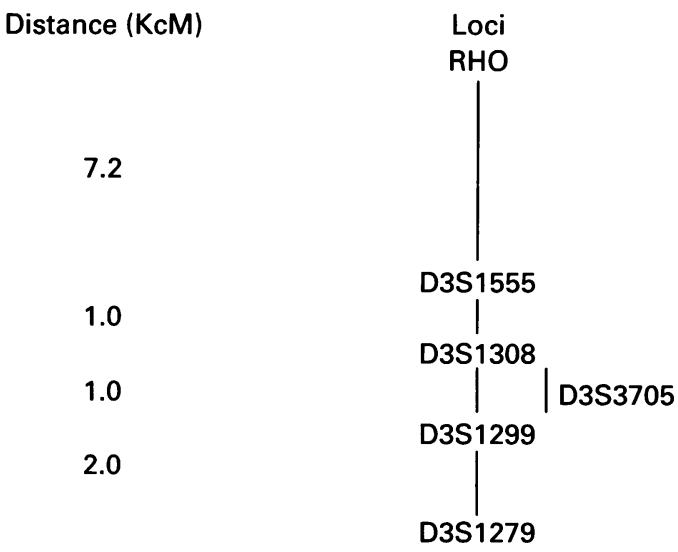

Figure 3 Genetic distances (KcM: Kosambi centimorgans) and locus order of the $3 q$ markers used. Data were obtained from Genome Data Bank (GDB) and Sankila et al. ${ }^{20}$

\section{LINKAGE ANALYSIS}

All the markers used in the present study were microsatellite markers, except for ROM1/2 which detects a polymorphism within intron 1 of the ROMI gene. ${ }^{34}{ }^{35}$ Pairwise and multipoint linkage analysis was performed using the MLINK and LINKMAP subroutines of version 5.1 of the LINKAGE program. ${ }^{36}$ The linear order of markers on chromosomes $11 \mathrm{q}^{37}$ and $3 \mathrm{q}^{20}$ and distances between them, are shown in figs 2 and 3. Penetrance was assumed to be 0.99 and the mode of inheritance was assumed to be autosomal recessive.

\section{Results}

Haplotype analysis (fig 1 ) suggested that in 12 of the 18 families $(67 \%)$, linkage for the USH1B locus existed. Pairwise lod scores for chromosome 11 marker loci are presented in table 3. Taking all 12 families together, pairwise linkage analysis gives lod scores of $14.032,7.259$, and 13.524 for D11S527, OMP, and D11S911 respectively, at zero recombination distance.

Table 4 Lod scores of chromosome 3 markers versus Usher type I in the two linked families

\begin{tabular}{|c|c|c|c|c|c|c|c|}
\hline & \multicolumn{7}{|c|}{ Recombination $(\theta)$} \\
\hline & 0.000 & 0.010 & 0.05 & 0.10 & 0.20 & 0.30 & 0.40 \\
\hline RHO & 1.454 & 1.428 & 1.318 & 1.172 & 0.847 & 0.492 & 0.158 \\
\hline D3S 1555 & 0.125 & 0.116 & 0.086 & 0.056 & 0.018 & 0.004 & 0.000 \\
\hline D3S 1308 & 1.153 & 1.127 & 1.020 & 0.883 & 0.599 & 0.320 & 0.245 \\
\hline D3S3705 & 0.505 & 0.487 & 0.416 & 0.332 & 0.185 & 0.079 & 0.019 \\
\hline D3S1299 & 0.852 & 0.830 & 0.742 & 0.630 & 0.408 & 0.206 & 0.056 \\
\hline D3S1279 & 1.880 & 1.838 & 1.669 & 1.450 & 0.992 & 0.536 & 0.157 \\
\hline
\end{tabular}
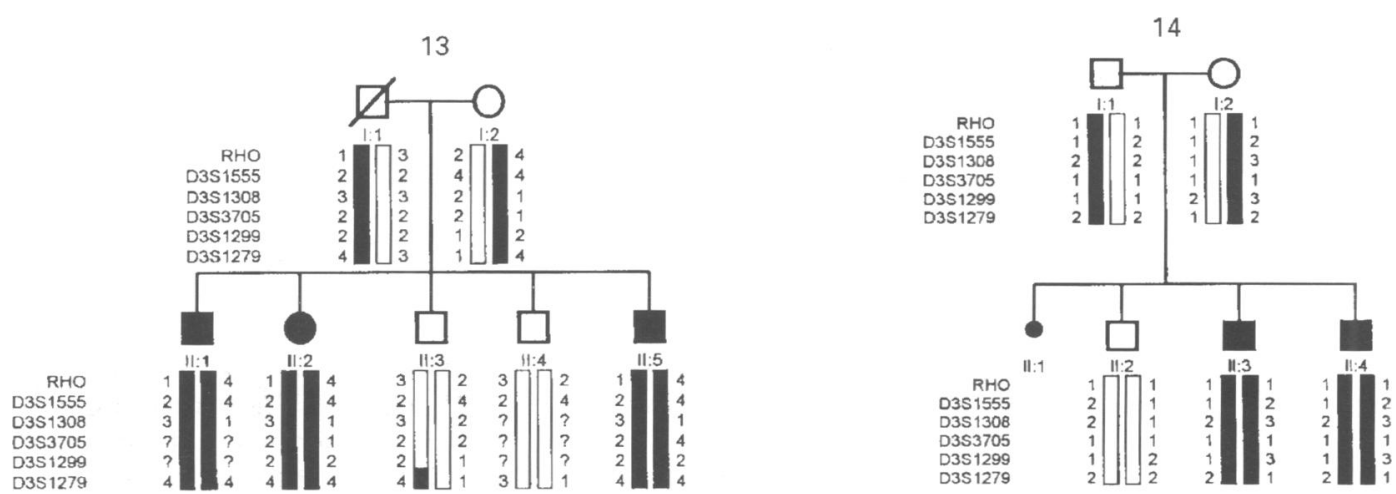

Figure 4 Pedigrees and haplotypes of the two Usher syndrome type I families linked to $3 q$. Haplotypes were constructed based on the minimum number of recombinations between these markers. 
Family 15
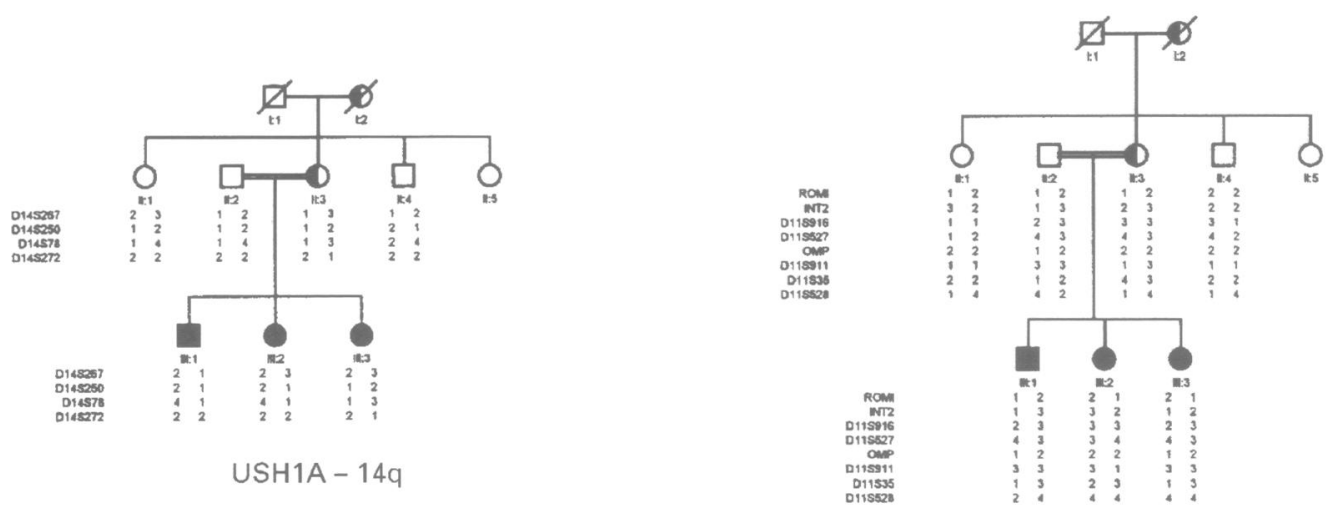

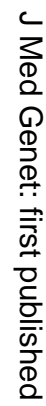

USH1B $-11 q$
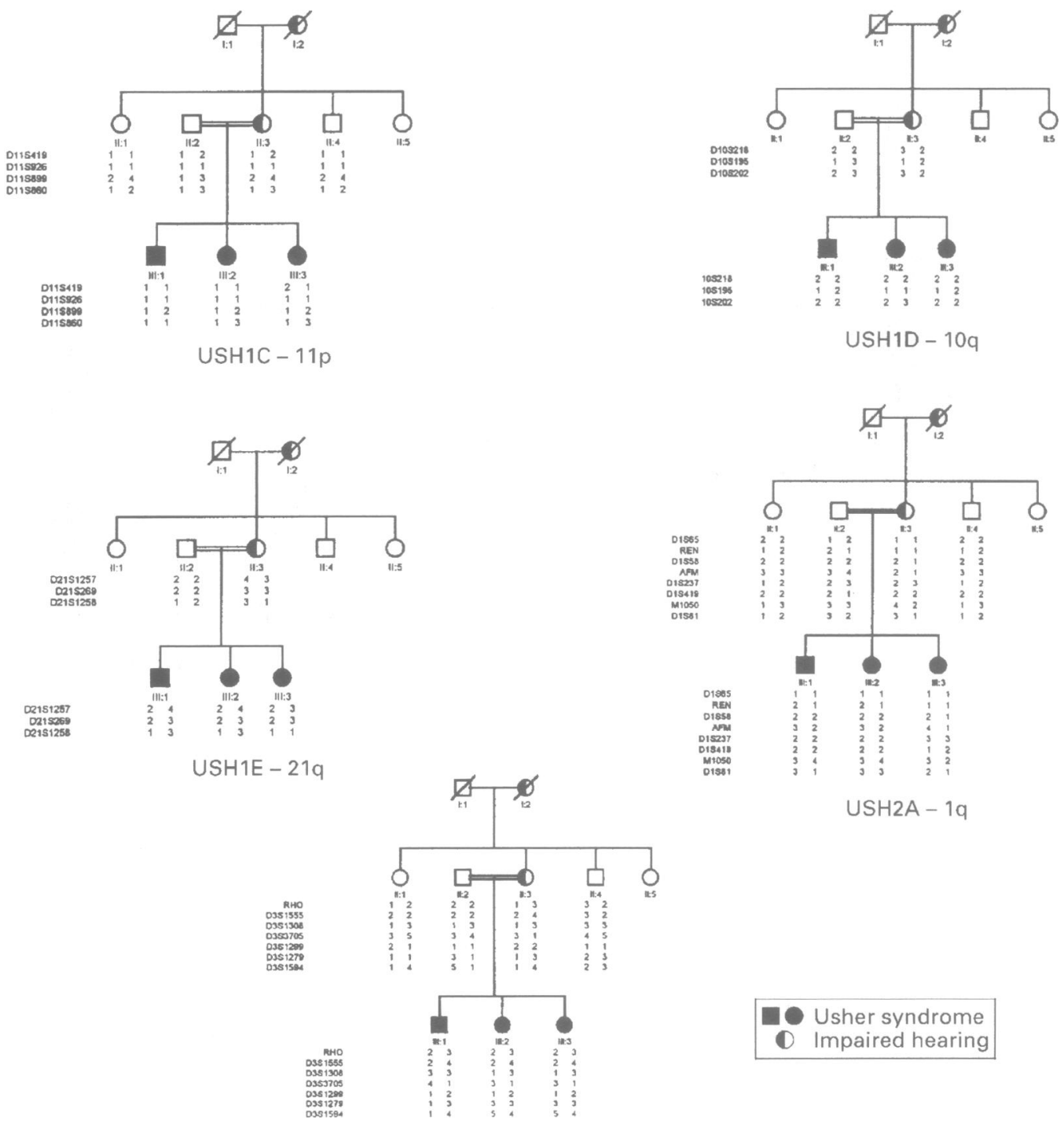

USH2A - 1q

USH 3 - 3q

Figure 5 Pedigrees and haplotypes of the families unlinked to any known Usher locus. Haplotypes were constructed based on the minimum number of recombinations between these markers.

Family 11 shows linkage to markers placed on chromosome $11 \mathrm{q}$ if we assume that patient II.4 is affected with USH1. If only the two females are considered as affected, this family fails to show linkage to any of the USH loci described.

In the 12 families linked to $11 \mathrm{q}$, none of the alleles that closely flank USH1B displayed significant differences between gene frequencies of the parental USH1B chromosomes and the normal parental chromosomes, which indicates that linkage disequilibrium is not present in this Spanish sample.

The remaining six USH1 families were studied with markers located in other Usher candidate regions: 14q32, $11 \mathrm{p} 15.1,10 \mathrm{q}, 21 \mathrm{q} 21$, $3 q 21-q 25$, and $1 \mathrm{q} 42$. For two of the families (fig 4), slightly positive lod scores were 

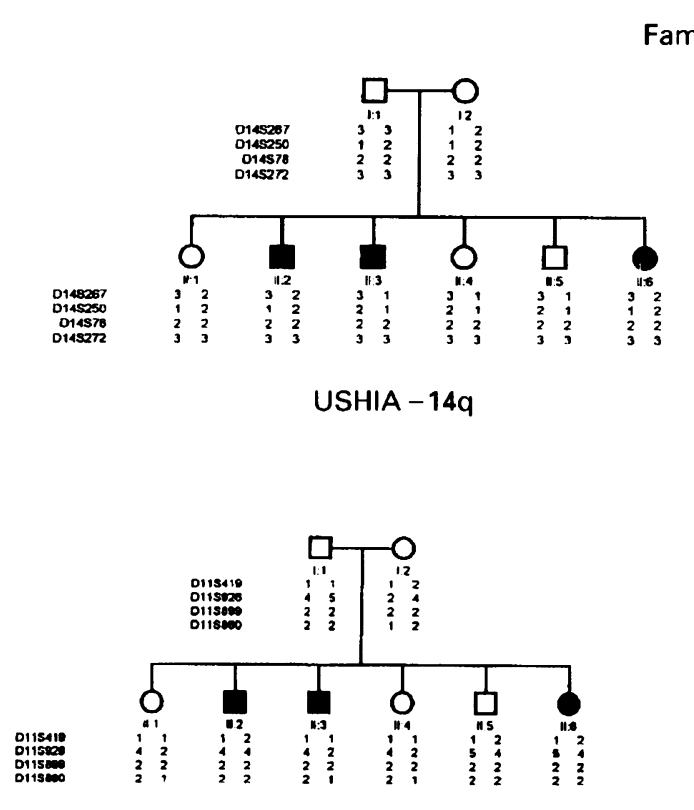

USHIC $-11 p$

Family 16
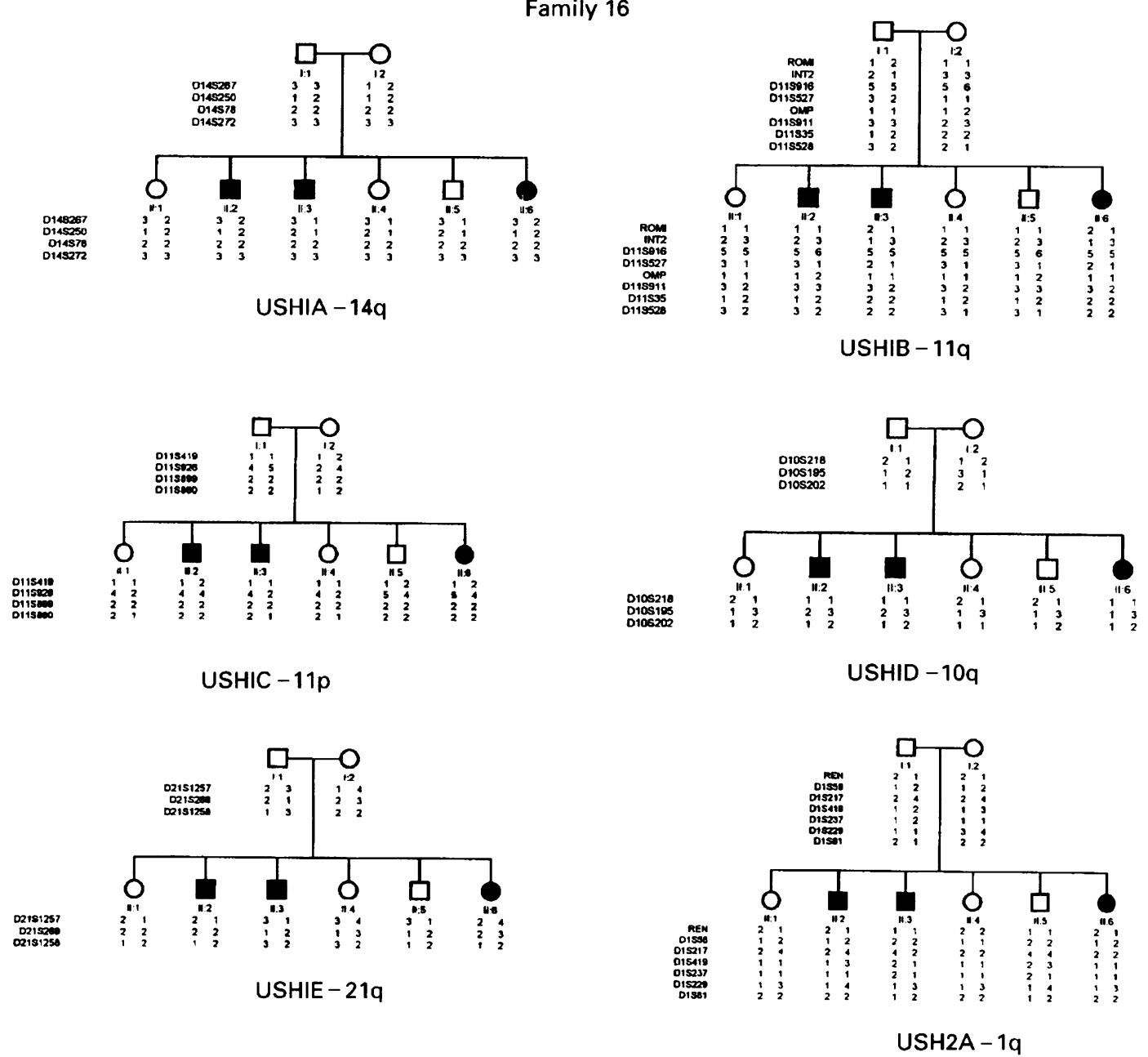

Figure 5 (cont).

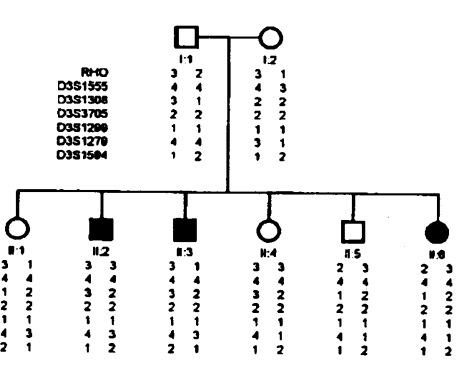

USH3-3q

observed for five markers located on chromosome $3 \mathrm{q} \quad(Z \max =1.880, \theta=0.000$ for D3S1279) (table 4). For the remaining four USH1 families (fig 5), no conclusive evidence of linkage to any loci previously described was obtained.

With respect to family 15 , which includes three sibs with clinical symptoms of USH 1 , it is important to note that the mother suffers profound bilateral sensorineural deafness, difficult but intelligible speech, normal vestibular response, and absence of RP. The father had no ocular or otological symptoms. The dead grandmother, who was not investigated, also had a hearing impairment of unknown degree. Taking this family as USH1, segregation of the disease with markers of the loci described was not observed.

\section{Discussion}

Even though a high percentage of the 18 USH 1 Spanish families studied are linked to chromo- some $11 \mathrm{q}(67 \%)$, there are an important number of cases $(33 \%)$ that fail to show linkage to either $11 \mathrm{q}$ or other known regions for USH1 (11p, 14q, 10q, or 21q). The results indicate considerable genetic heterogeneity in these USH1 families. For the $11 \mathrm{q}$ linked cases, lod scores obtained here are in agreement with those previously reported elsewhere with respect to the physical mapping and localisation of USH1B. These new data, thus, place the candidate gene in the region between D11S527 and D11S911, which is compatible with other reports $^{12}{ }^{13}$ and which, although we have not yet analysed mutations in the myosin gene, supports the role of this gene in the pathogenesis of USH1B families. ${ }^{22-24} 3839$ These results also discount the possible involvement in the USH1 syndrome of other genes formerly considered candidates, such as ROMI and INT2, ${ }^{12}{ }^{35}$ since recombinant events have been found with these loci. 


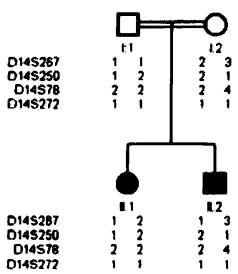

USH1A - 14q

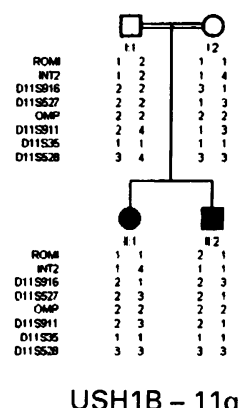

USH1B - 11q
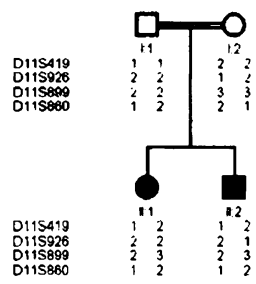

0105218
D1105195
0105202

0.105218
0105185
0105202

USH1C-11p

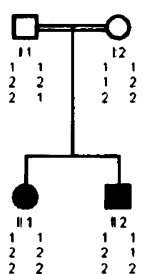

USH1D - 10q

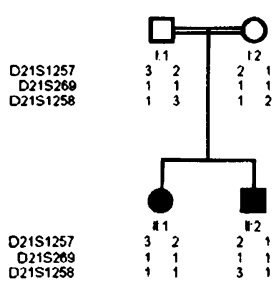

USH1E - 21q

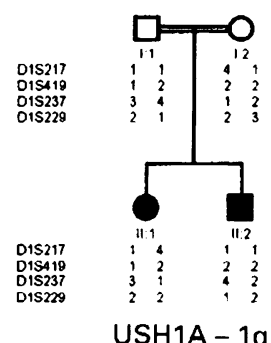

USH1A - 1q
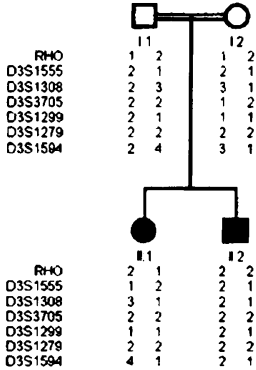

USH $3-3 q$

Family 18
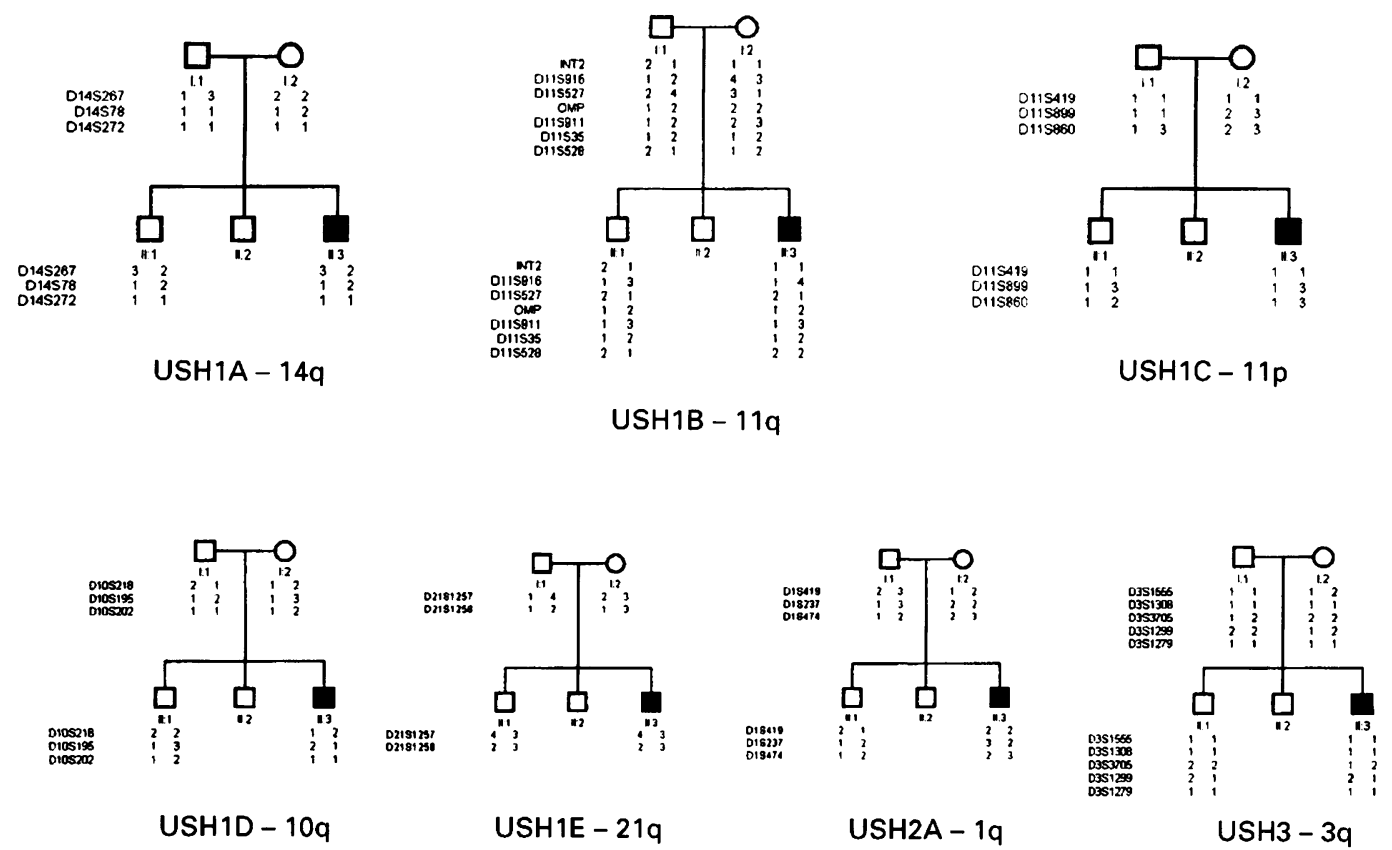

Figure 5 (cont).

It is important to emphasise that at least two of the USH1 families in this study show positive lod scores for markers located on chromosome 3q. This chromosomal region is exactly the same as that in which Sankila et $a l^{20}$ and, to a lesser extent, Kimberling et $a l^{1}$ reported linkage for USH3 families from Finland and for some Swedish USH2 families, respectively. To date, families classified as USH1 have not been found to be related to this locus, although the possibility that some USH3

patients show a phenotype similar to USH1 or USH2 has already been suggested. ${ }^{40}$ Lod scores are not high, but they contrast with the negative results for markers located on chromosome 3q shown by the other USH 1 families linked to $11 \mathrm{q}$ or unlinked to the other loci described, and also with the data obtained for markers placed in other candidate regions in these two families.

Vestibular function is a reliable and consistent discriminator between Usher types I and II 
since most, if not all, type I patients lack vestibular function. ${ }^{41}$ There are, nevertheless, cases of USH2 and USH3 in which some abnormal vestibular response is reported. ${ }^{62}$ In this study, families 1 to 18 could not be diagnosed as USH2 or USH3 since they had severely abnormal vestibular function and profound congenital prelingual hearing loss leading to total deaf-mutism. Similarly, the onset of $\mathrm{RP}$ is not conclusive for differentiation of the three types. ${ }^{43}$ Therefore, according to the present results and to others which are similar, ${ }^{20}{ }^{21}$ families classified as USH1, USH2, and USH3 have all shown linkage to 3q. It would be interesting to re-examine the clinical parameters, owing to the wide range of clinical symptoms in every Usher type, and to perform genotype-phenotype correlations in order to discriminate between the different types and to investigate whether some of them may be the result of allelic manifestations of a single gene.

It is important to stress the special clinical aspects of family 11 , which has in the same sibship two affected females who show a typical USH1 phenotype and one male who suffers profound hearing impairment and absence of RP. This family has been considered as USH1, mainly because of linkage to $11 \mathrm{q}$ markers. Moreover, since allelic variants of the myosin VIIA gene may be involved in both USH1B syndrome and an isolated form of deafness (DFNB2) ${ }^{4445}$ the possibility that a mutation in this gene is responsible for the phenotypic variability within this family cannot be discarded. It is also interesting to note that the same genomic region is involved in a dominant form of non-syndromic deafness (DFNA11). ${ }^{46}$ This phenomenon has already been observed in other chromosome regions (DFNA3 and DFNB1 to $13 \mathrm{q} 11,{ }^{47}{ }^{48}$ DFNA9 and DFNB5 to $\left.14 \mathrm{q} 12^{49}\right)$.

Family 15 may represent a similar example to family 11 , since it also presents intrafamilial clinical variability if we consider members of different generations. This family remains unlinked to any Usher locus described to date. It could be possible that one mutation in an unknown gene is responsible for syndromic and non-syndromic forms of hearing loss within this family. If this supposition were correct, each family would represent an example of a single mutation responsible for syndromic and isolated forms of deafness.

The authors would like to thank the patients and their family members for their help and cooperation. We acknowledge the Asociacion de retinosis pigmentaria de la Comunidad Valenciana, the FAARPEE, ONCE, Fundacion ONCE, and the Fondo de Investigaciones Sanitarias (FISS No 95/1814) for financial support.

1 Usher CH. Bowman's lecture: on a few hereditary eye affections. Trans Ophthal Soc UK 1935;55:164-245.

2 Hallgren B. Retinitis pigmentosa combined with congenital deafness; with vestibulo-cerebellar ataxia and mental abnormality in a proportion of cases. A clinical and abnormality in a proportion of cases. A clinical and
genetico-statistical study. Acta Psychiatr Scand 1959; 34(suppl 138):5-101.

3 Kimberling WJ, Möller CG, Davenport SLH, et al. Usher syndrome: clinical findings and gene localization studies. Laryngoscope 1989;99:66-72.

4 Tamayo ML, Bernal JE, Tamayo GE, et al. Usher syndrome: results of a screening program in Colombia. Clin Genet 1991;40:304-11.

5 van Aarem A, Cremers CWRJ, Pinckers AJLG, Huygen PLM, Hombergen GCJH, Kimberling BJ. The Usher syn- drome type 2A: clinical findings in obligate carriers. Int $f$ Pediatr Otorhinolaryngol 1995;31:159-74

6 Gorlin RJ, Tilsner TJ, Feinstein S, Duvall AJ. Usher's syndrome type III. Arch Otolaryngol 1979;105:353-4.

7 Karjalainen S, Pakarinen L, Terasvirta M, Kaarianen $H$, Vartiainen E. Progressive hearing loss in Usher's syndrome. Ann Otol Rhinol Laryngol 1989;98:863-6.

8 Karjalainen S, Teräsvirta $M$, Käriä J, Kääriäinen $H$. Usher's syndrome type III: ENG findings in four affected and six unaffected siblings. $\mathcal{F}$ Laryngol Otol 1985;99:43-8.

9 Wagenaar M, ter Rahe B, van Aarem A, et al. Clinical findings in obligate carriers of type I Usher syndrome. $A m \mathcal{F}$ Med Genet 1995;59:375-9.

10 Kaplan J, Gerber S, Bonneau D, et al. A gene for Usher syndrome type I (USH1A) maps to chromosome 14q. Genomics 1992; 14:979-87.

11 Larget-Piet D, Gerber S, Bonneau D, et al. Genetic heterogeneity of Usher syndrome type $I$ in French families. Genomics 1994;21:138-43.

12 Kimberling WJ, Weston MD, Möller CG, et al. Linkage of Usher syndrome type I gene (USH1B) to the long arm of chromosome 11. Genomics 1992;14:988-94.

13 Bonné-Tamir B, Korostishevsky M, Kalinsky $\mathrm{H}$, et al. Genetic mapping of the gene for Usher syndrome: linkage analysis in a large Samaritan kindred. Genomics 1994;20 36-42.

14 Keats BJB, Nouri N, Pelias MZ, Deininger PL, Litt $M$ Tightly linked flanking microsatellite markers for the Usher syndrome type I locus on the short arm of chromosome 11. Am 7 Hum Genet 1994;54:681-6.

15 Smith RJH, Lee EC, Kimberling WJ, et al. Localization of two genes for Usher syndrome type I to chromosome 11. Genomics 1992;14:995-1002.

16 Wayne S, Der Kaloustian VM, Schloss M, et al. Localization of Usher syndrome type ID gene (USH1D) to chromosome 10. Hum Mol Genet 1996;5:1689-92.

17 Chaib H, Kaplan J, Gerber S, et al. A newly identified locus for Usher syndrome type I, USH1E, maps to chromosome 21q21. Hum Mol Genet 1997;6:27-31.

18 Kimberling WJ, Weston MD, Möller CG, et al. Localization of Usher syndrome type II to chromosome 1q. Genomics 1990;7:245-9.

19 Lewis RA, Otterud B, Stauffer D, Lalouel JM, Leppert M Mapping recessive ophthalmic diseases: linkage of the locus for Usher syndrome type II to a DNA marker on chromosome 1q. Genomics 1990;7:250-6.

20 Sankila EM, Pakarinen L, Kääriäinen $\mathrm{H}$, et al. Assignmen Sankila EM, Pakarinen L, Kaariainen $\mathrm{H}$, et al. Assignment
of an Usher syndrome type III (USH3) gene to of an Usher syndrome type III (USH3)
chromosome 3q. Hum Mol Genet 1995;4:93-8.

21 Kimberling WJ, Weston MD, Möller C, et al. Gene mapping of Usher syndrome type IIa: localization of the gene to a $2.1-\mathrm{cM}$ segment on chromosome 1q41. Am $\mathcal{F}$ Hum Genet 1995;56:216-23.

22 Weil D, Blanchard S, Kaplan J, et al. Defective myosin VIIA gene responsible for Usher syndrome type 1B. Nature 1995;374:60-1.

23 Weston MD, Kelley PM, Overbeck LD, et al. Myosin VIIA mutation screening in 189 Usher syndrome type I patients. Am ₹ Hum Genet 1996;59:1074-83.

24 Lévy G, Levi-Acobas F, Blanchard S, et al. Myosin VIIA gene: heterogeneity of the mutations responsible for Usher gene: heterogeneity of the mutations responsible for

25 Kunkel LM, Tantravah U, Eisenhard M, Latt SA. Regional localization on the human X of DNA sequences cloned from flow shorted chromosomes. Nucleic Acids Res 1982;10:1557-71

26 Nichols BE, Bascom R, Litt M, McInnes R, Sheffield VC, Stone EM. Refining the locus for Best vitelliform macular dystrophy and mutation analysis of the candidate gene ROM1. Am F Hum Genet 1994;54:95-103.

27 Polymeropoulos $\mathrm{MH}$, Xiao H, Rath DS, Merril CR. Dinucleotide repeat polymorphism at the int-2 proto-oncogene locus. Nucleic Acids Res 1990;18:7468.

28 Pieke-Dahl S, Weston MD, Overbeck LD, Evans KL, Porteous DJ, Kimberling WJ. Dinucleotide repeat polymorphism at the human olfactory marker protein (OMP) locus phism at the human olfactory marker protein (OMP) locus
on chromosome $11 \mathrm{q} 13.5$ near tyrosinase (TYR). Hum Mol Genet 1993;2:822.

29 Gyapay G, Morissette J, Vignal A, et al. The 1993-94 Généthon human genetic linkage map. Nat Genet 1994;7:246339.

30 Brown DL, Gault J, Thompson MB, Hauge XY, Evans GA Litt M. Dinucleotide repeat polymorphisms at the D11S527 locus. Nucleic Acids Res 1991;19:4790.

31 Litt M, Sharman V, Luty JA. Dinucleotide repeat polymorphism at the D11S35 locus. Nucleic Acids Res 1990;18: 5921.

32 Hauge XY, Evans GA, Litt M. Dinucleotide repeat polymorphisms at the D11S528 locus. Nucleic Acids Res polymorphism

33 Weber JL, May PE. Abundant class of human DNA polymorphisms which can be typed using the polymerase polymorphisms which can be typed using the polyn

34 Bascom RA, Garcia-Heras J, Hsieh GL, et al. Localization of the photoreceptor gene ROMI to human chromosome 11 and mouse chromosome 19: sublocalization to human 11 q1 3 between PGA and PYGM. Am f Hum Genet 1992; 51:1028-35.

35 Bascom RA, Liu L, Humphries P, Fishman GA, Murray JC, McInnes RR. Polymorphisms and rare sequence variants a the ROMI locus. Hum Mol Genet 1993;2:1975-7.

36 Lathrop GM, Lalouel JM, Julier C, Ott J. Multilocus linkage analysis in humans: detection of linkage and estimation of recombinations. Am $\mathcal{f}$ Hum Genet 1985;37:482-98. 
37 van Heyningen V, Little PFR. Report of the fourth international workshop on human chromosome 11 mapping 1994. Cytogenet Cell Genet 1995;69:128-58.

38 Hasson T, Heintzelman MB, Santos-Sacchi J, Corey DP, Mooseker MS. Expression in cochlea and retina of myosin VIIa, the gene product defective in Usher syndrome typ 1B. Proc Natl Acad Sci USA 1995;92:9815-19.

39 El-Amraoui A, Sahly I, Picaud S, Sahed J, Abitbol M, Petit C. Human Usher 1B/mouse shaker-1: the retinal phenotyp discrepancy explained by the presence/absence of myosin VIIA in the photoreceptor cells. Hum Mol Genet 1996;5 1171-8.

40 Pakarinen L, Sankila EM, Tuppurainen K, Karjalainen S, Kääriäinen $\mathrm{H}$. Usher syndrome type III (USH3): the clinical manifestations in 42 patients. Scand 7 Log Phon 1995;20:141-50.

41 Kimberling WJ, Möller C. Clinical and molecular genetics of Usher syndrome. $₹$ Am Acad Audiol 1995;6:63-72.

42 Smith RJH, Berlin CI, Hejmancik JF, et al. Clinical diagnosis of the Usher syndromes. Am $\mathcal{J}$ Med Genet 1994;50:32-8.

43 Pakarinen L, Tuppurainen K, Laippala S, Mäntyjärvi M Puhakka H. The ophthalmological course of Ushe syndrome type III. Int Ophthalmol 1996;19:307-11.
44 Liu XZ, Walsh J, Mburu P, et al. Mutations in the myosin VIIA gene cause non-syndromic recessive deafness. Nat Genet 1997;16:188-90.

45 Weil D, Küssel P, Blanchard S, et al. The autosoma recessive isolated deafness, DFNB2, and the Usher $1 \mathrm{~b}$ syndrome are allelic defects of the myosin-VIIA gene. $\mathrm{Nat}$ Genet 1997;16:1991-3.

46 Tamagawa Y, Kitamura K, Ishida $\mathrm{T}$, et al. A gene for a dominant form of non-syndromic sensorineural deafness (DFNA11) maps within the region containing the DFNB2 recessive deafness gene. Hum Mol Genet 1996;5:849-52.

47 Chaib H, Lina-Granade G, Guilford P, et al. A gene responsible for a dominant form of neurosensory non-syndromic deafness maps to the NSRD1 recessive deafness gene interval. Hum Mol Genet 1994;3:2219-22.

48 Kelssell DP, Dunlop J, Stevens HP, et al. Connexin 26 mutations in hereditary non-syndromic sensorineural deafness. Nature 1997;387:80-3

49 Manolis EN, Yandavi N, Nadol JB Jr, et al. A gene for nonsyndromic autosomal dominant progressive postlingual syndromic autosomal dominant progressive postlingual Hum Mol Genet 1996;5:1047-50. 